Ljubiša Vladušić ${ }^{1}$

University of East Sarajevo, Faculty of Economics,

Bosnia and Hezegovina

Aleksandar Živković ${ }^{2}$

University of Belgrade, Faculty of Economics

Nemanja Pantić3

University of Kragujevac, Faculty of Hotel Management and Tourism
SCIENTIFIC REVIEW ARTICLE doi:10.5937/ekonomika2001065V

Received: October, 11. 2019.

Accepted: December, 21. 2019.

\title{
MACROECONOMIC ANALYSIS OF GDP AND EMPLOYMENT IN EU COUNTRIES
}

\begin{abstract}
In modern countries, there is request for focusing on budget policy. It is consequence of the weaknesses of previous ones. These policies were created to eliminate the resulting disparities in the past and they were successful in solving those problems, neglecting some categories whose negative effects will manifest later. The importance of achieving an adequate rate of GDP growth as well as employment is in the center of almost all economic policies. The differences are in the instruments and measures that must be taken to achieve them. This article addresses precisely these goals of macroeconomic stability and the correlation that exists among these categories. Proving this correlation is important because the adopted policies can be monitored more effectively, but on the other hand will serve as a reminder of the importance of the measures adopted in these categories and the related macroeconomic stability. The SPSS software package was used and its correlation and regression analysis to prove the dependency, and the data will serve as a theoretical overview of GDP and employment trends in EU.
\end{abstract}

Key words: gross domestic product (GDP), employment, European Union.

JEL classification: E23, E24

\section{МАКРОЕКОНОМСКА АНАЛИЗА ГДП И ЗАПОСЛЕНОСТИ У ЗЕМЉАМА ЕВРОПСКЕ УНИЈЕ}

\section{Апстракт}

Код савремених држава се намеће неоиходности усмеравана ка буиейској йолитиии. Она је ирроистекла из слабостии, односно недостиайака иреитходних

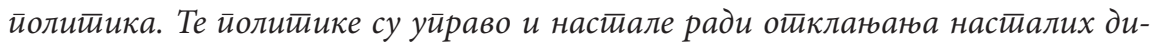
сиройориија у ирошлостии и биле су усиетне у йоме, занеамрујући неке кайегорије чије ће се негайивно дејстиво иекк касније исиолийи. Значај досииизана

\footnotetext{
${ }^{1}$ ljubisa.vladusic@ekofis.ues.rs.ba, ORCID ID: https://orcid.org/0000-0001-9291-3787

2 aca@ekof.bg.ac.rs, ORCID ID: https://orcid.org/0000-0001-5696-5774

${ }_{3}^{3}$ pantic.nemanja85@gmail.com, ORCID ID: https://orcid.org/0000-0003-0030-6950
} 


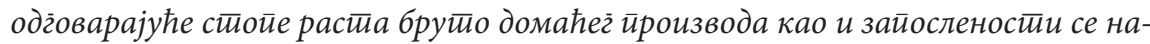
лази у средишйу готиово свих економских йолииика. Разлике су у инстирумениима и мерама које је неоиходно иреузетии ради юиховог остиваривағь. Овај рад се бави уирраво овим иитевима макроекономске стиабилности и корелације која йосйоји међу овим каиегоријама. Доказиване ове корелаиије има значаја

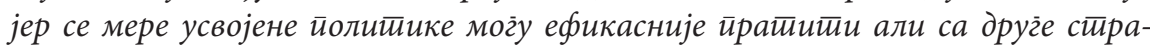
не ће йослужити као йодсейник значаја усвојених мера на ове кайегорије и са юом йовезане макроекономске стиабилностии. За доказиваюе зависности се

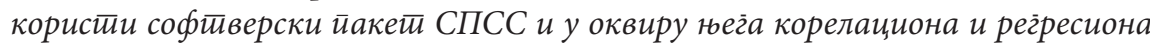

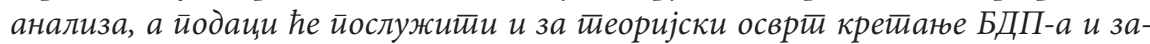
йосленостии на нивоу Евройске уније.

Клучне речи: бруйо домаћи йроизвод, зайосленосй, Евройска Унија.

\section{Introduction}

Gross domestic product (GDP) is considered to be one of the most significant indicators of the country's economic development. It is certainly not the only one, but its movement is one of the most significant indicators of the successful implementation of appropriate economic policy measures. Many theorists talked about its importance and impact on the value of GDP is at the centre of almost all theories. In developed EU economies, there is the increase in public expenditures, fiscal revenues and budget deficits at all levels of institutional organization of public sector financing. Because of all these features and characteristics, it is accepted indicator of the healthiness of a country's economy and therefore economists, financial analysts, consultants, managers, economic policy makers, and politicians are interested in its movement.(Dugalić, 2017) There are frequent comparisons of GDP and other macroeconomic indicators(Kovačević \& Pavlović, 2016) to establish a link between them. This paper will show whether there is a correlation between GDP and employment. The importance of examining this dependency is crucial to the effects of economic policies.(Popescu, 2016; Simić, Kosumi \& Jialiang, 2019) Employment growth has multiplied effects on the economy.(Myślińska, 2006) Its increase reduces social transfers to unemployed persons but also increases production, which can again affect employment growth. The basic postulate of Keynesian theoretical thought was to achieve a level of full employment whereby the role of money was put aside and had a secondary importance. This resulted in major inflationary shocks that can drag the economy into a recession phase. When it comes to that stage of the economic cycle, production falls, and consequently, employment and finally GDP. This mechanism is an indicator of the importance of a systematic approach in defining economic development policies that will consider all elements of macroeconomic stability and their synergistic effect.(Joldić, Vasiljević \& Krstić, 2018) Entering into a prosperous phase of the economic cycle and the associated GDP, and employment growth, will attract additional investment. (Mordecki, \& Ramirez, 2018) Growth in investment activity will again induce GDP and employment growth but also a positive foreign trade balance. (Ines, Cinzia, 2009). 


\section{Theoretical review of GDP and employment growth rates in EU Member States}

This part of the article will show GDP growth and employment rates in EU member states. Analyzed data refer to the last quarter of 2017 and the all thre quarters of 2018 and after that will be made statistical analysis and the results will be presented in the discussion section of the results.

Table 1: Unemployment rates in the EU Member States for 2018.

\begin{tabular}{|c|c|c|c|}
\hline State & Unemployment \% & State & Unemployment \% \\
\hline Czech Republic & 2.2 & Belgium & 6.4 \\
\hline Malta & 3.3 & Estonia & 6.5 \\
\hline Germany & 3.4 & EU-28 & 7.1 \\
\hline Hungary & 3.7 & Portugal & 7.4 \\
\hline Netherlands & 3.9 & Lithuania & 7.5 \\
\hline UK & 4.1 & Slovakia & 7.5 \\
\hline Poland & 4.4 & Latvia & 7.9 \\
\hline Romania & 4.5 & Finland & 8.2 \\
\hline Denmark & 4.8 & EA-19 & 8.5 \\
\hline Austria & 5.0 & France & 8.8 \\
\hline Bulgaria & 5.2 & Cyprus & 9.1 \\
\hline Slovenia & 5.2 & Croatia & 9.4 \\
\hline Luxembourg & 5.4 & Italy & 11.0 \\
\hline Ireland & 6.1 & Spain & 16.1 \\
\hline Sweden & 6.2 & Greece & 20.6 \\
\hline
\end{tabular}

Source: Eurostat

In Table 1, countries are ranked by increasing unemployment rate, which can be used for comparation of its percentages. The Czech Republic has the lowest unemployment rate in the European Union with only $2.2 \%$ and is the only country with a lower unemployment rate then $3 \%$. The following group of countries includes those with unemployment rate up to $4 \%$, Malta (3.3\%), Germany (3.4\%), Hungary (3.7\%) and the Netherlands (3.9\%). The group of countries where unemployment rate is up to $5 \%$ belongs to the United Kingdom (4.1\%). Poland (4.4\%), Romania (4.5\%) and Denmark (4.8\%). Austria, Bulgaria, Slovenia and Luxembourg have unemployment rates of $5.0 \%$, $5.2 \%, 5.2 \%$ and $5.4 \%$ respectively. The unemployment rate in EU is $7.1 \%$, but most countries have an unemployment rate below the average. This majority is almost $71 \%$ of the Member States. Certainly this is out of the ordinary. The crisis that has been in 
Greece for more than a decade, as well as a huge amount of public debt and the decrease in gross domestic product (GDP) and thus employment, have a significant impact on this situation. Unemployment at the level of $20.6 \%$ certainly has a significant impact on the EU average unemployment rate. Less than $30 \%$ of countries have unemployment at EU level. Analyzing situation without Greece, EU average unemployment rate would be $6.4 \%$. The achieved level of employment is one of the most significant indicators of the level of economic development.(Ciuhu, \& Vasilie, 2018) Particularly painful for the transition countries is the employment and measures for increasing the number of employees are necessary factor for economic growth.(Đuričin, 2011) In addition to employment, GDP growth and inflation are indicators whose trends define the character of transition process. (Malešević-Perović, 2008)

Table 2: Quarterly employment growth rates in EU Member States

\begin{tabular}{|c|c|c|c|c|c|c|c|c|}
\hline \multirow{3}{*}{$\begin{array}{c}\text { Year } \\
\text { Quarters }\end{array}$} & \multicolumn{4}{|c|}{$\begin{array}{l}\text { Percentage change compared to the } \\
\text { previous quarter }\end{array}$} & \multicolumn{4}{|c|}{$\begin{array}{l}\text { The percentage change compared to } \\
\text { the same quarter of the previous year }\end{array}$} \\
\hline & \multirow{2}{*}{$\begin{array}{c}2017 \\
\mathbf{Q} 4\end{array}$} & \multicolumn{3}{|c|}{2018} & \multirow{2}{*}{$\begin{array}{c}2017 \\
\text { Q4 }\end{array}$} & \multicolumn{3}{|c|}{2018} \\
\hline & & Q1 & Q2 & Q3 & & Q1 & Q2 & Q3 \\
\hline \multicolumn{9}{|c|}{ States } \\
\hline Belgium & 0.3 & 0.3 & 0.3 & 0.4 & 1.2 & 1.2 & 1.1 & 1.4 \\
\hline Bulgaria & 0.4 & 0.0 & -0.2 & -0.3 & 2.4 & 1.2 & 0.2 & -0.9 \\
\hline Czech Republic & 0.0 & 0.6 & 0.6 & 0.0 & 1.4 & 1.8 & 1.9 & 1.1 \\
\hline Denmark & 0.4 & 0.6 & 0.4 & 0.3 & 1.7 & 1.9 & 2.0 & 1.8 \\
\hline Germany & 0.3 & 0.5 & 0.2 & 0.3 & 1.4 & 1.5 & 1.3 & 1.3 \\
\hline Estonia & 1.4 & -1.4 & 1.3 & -0.8 & 5.7 & 0.9 & 2.7 & 0.5 \\
\hline Ireland & 1.2 & 0.7 & 0.7 & - & 3.5 & 3.2 & 3.4 & - \\
\hline Greece & -0.1 & 0.5 & 1.0 & 0.0 & 1.9 & 1.6 & 1.7 & 1.4 \\
\hline Spain & 0.4 & 0.5 & 0.7 & 0.4 & 2.5 & 2.1 & 2.2 & 2.0 \\
\hline France & 0.3 & 0.3 & 0.1 & 0.1 & 1.4 & 1.3 & 1.0 & 0.8 \\
\hline Croatia & 0.2 & 0.4 & 0.0 & -0.2 & 3.8 & 4.6 & 2.3 & 0.3 \\
\hline Italy & -0.3 & 0.2 & 0.6 & -0.3 & 0.9 & 0.4 & 1.1 & 0.3 \\
\hline Cyprus & 1.0 & 0.7 & 1.0 & 0.8 & 4.4 & 4.3 & 4.3 & 3.7 \\
\hline Latvia & 0.9 & 0.9 & -0.3 & 0.7 & 0.9 & 1.7 & 2.0 & 2.2 \\
\hline Lithuania & 0.2 & 0.0 & 0.7 & 0.8 & -0.5 & 0.1 & 0.5 & 1.7 \\
\hline Luxembourg & 1.1 & 1.0 & 0.9 & 0.7 & 3.6 & 3.7 & 3.8 & 3.7 \\
\hline Hungary & 0.7 & 0.7 & 0.5 & 0.5 & 2.0 & 2.4 & 2.3 & 2.3 \\
\hline Malta & 1.4 & 1.4 & 1.4 & 0.9 & 4.8 & 5.6 & 6.0 & 4.9 \\
\hline
\end{tabular}




\begin{tabular}{|c|c|c|c|c|c|c|c|c|}
\hline Netherlands & 0.7 & 0.7 & 0.5 & 0.6 & 2.3 & 2.6 & 2.4 & 2.5 \\
\hline Austria & 0.6 & 0.3 & 0.4 & 0.3 & 1.8 & 1.9 & 1.9 & 1.6 \\
\hline Poland & -0.5 & 0.2 & 1.3 & -0.2 & 0.5 & 0.4 & 0.7 & 0.9 \\
\hline Potrugal & 0.7 & 0.8 & 0.0 & 0.5 & 3.2 & 3.2 & 2.1 & 2.1 \\
\hline Romania & -0.2 & 0.7 & -0.1 & -0.1 & 2.1 & 1.8 & -1.5 & 0.2 \\
\hline Slovenia & 0.8 & 0.8 & 0.7 & 0.7 & 3.0 & 3.3 & 3.0 & 2.8 \\
\hline Slovakia & 0.6 & 0.5 & 0.5 & 0.4 & 2.2 & 2.2 & 2.1 & 1.9 \\
\hline Finland & 1.0 & 0.9 & 0.6 & 0.3 & 2.1 & 2.3 & 2.9 & 2.7 \\
\hline Sweden & 0.4 & 0.5 & 0.3 & 0.3 & 2.1 & 2.0 & 1.7 & 1.6 \\
\hline UK & 0.3 & 0.6 & 0.1 & 0.1 & 1.0 & 1.3 & 1.0 & 1.1 \\
\hline
\end{tabular}

Source: Eurostat

If we look at the percentage changes in consecutive quarters, we can see that are positive in almost all countries, which leads to the conclusion that employment almost exclusively increased in almost all countries in 2018 and the last quarter of 2017. This situation is the goal of every market economy and a precondition for achieving positive results and trends in other indicators of macroeconomic stability.(Zrinščak, 1997) There are significant deviations from the positive trend in Bulgaria because in the second quarter employment felt by $0.2 \%$ and in the third by $0.3 \%$. The biggest decline was achieved in the first quarter of 2018 in Estonia, where it decreased by $1.4 \%$, offset by a $1.3 \%$ increase already in the next quarter. In Romania, there has been a decline in employment in three of the last four quarters and in the first quarter of 2018 there was a $0.7 \%$ increase in employment. If we compare the quarters of one year with the same in the previous one, we can also see a positive trend. As the comparison period is longer the percentages will be certainly higher as they are related to the period of one year.

Employment decreased by $0.9 \%$ in the third quarter of 2018 compared to the same in 2017. The second and last case of the decrease in employment was recorded in the second quarter of Romania, where the employment rate was $1.5 \%$ lower than in the same quarter of the previous year. The highest employment growth was recorded in Estonia in the last quarter of 2017 and was $5.7 \%$. In other countries, consiedring a period of one year, employment is rising, which is certainly a consequence of a well-managed budgetary policy and the achievement of one of the basic macroeconomic goals - employment. The importance of achieving a satisfactory level of employment is enormous because underemployment, by all macroeconomic indicators, has the most negative consequences. (Paul, 2001). The negative impact of rising unemployment is reflected in all spheres of social life.(Winkelmann, \& Winkelmann, 1997)

In addition to the employment rate, more detailed statistical analysis also requires data on GDP growth rates, which can be found in the following table. 
Table 3: Growth rates of GDP by quarters in EU Member States

\begin{tabular}{|c|c|c|c|c|c|c|c|c|}
\hline \multirow{3}{*}{$\begin{array}{c}\text { Year } \\
\text { Quarters }\end{array}$} & \multicolumn{4}{|c|}{$\begin{array}{l}\text { Percentage change compared to the } \\
\text { previous quarter }\end{array}$} & \multicolumn{4}{|c|}{$\begin{array}{l}\text { The percentage change compared to } \\
\text { the same quarter of the previous year }\end{array}$} \\
\hline & \multirow{2}{*}{$\begin{array}{r}2017 \\
\mathrm{Q} 4 \\
\end{array}$} & \multicolumn{3}{|c|}{2018} & \multirow{2}{*}{$\begin{array}{c}2017 \\
\mathrm{Q} 4 \\
\end{array}$} & \multicolumn{3}{|c|}{2018} \\
\hline & & Q1 & Q2 & Q3 & & Q1 & Q2 & Q3 \\
\hline \multicolumn{9}{|c|}{ States } \\
\hline Belgium & 0.7 & 0.3 & 0.3 & 0.3 & 1.9 & 1.5 & 1.4 & 1.6 \\
\hline Bulgaria & 0.7 & 0.9 & 0.8 & 0.7 & 3.5 & 3.5 & 3.4 & 3.1 \\
\hline Czech Republic & 0.7 & 0.5 & 0.7 & 0.6 & 5.0 & 4.1 & 2.4 & 2.4 \\
\hline Denmark & 0.8 & 0.4 & 0.2 & 0.7 & 0.9 & -1.1 & 0.2 & 2.0 \\
\hline Germany & 0.5 & 0.4 & 0.5 & -0.2 & 2.8 & 2.0 & 1.9 & 1.2 \\
\hline Estonia & 1.9 & 0.1 & 1.4 & 0.4 & 4.9 & 3.5 & 3.8 & 3.9 \\
\hline Ireland & 2.6 & -0.4 & 2.5 & - & 5.4 & 10.2 & 9.1 & - \\
\hline Greece & 0.2 & 0.5 & 0.4 & 1.0 & 2.1 & 2.5 & 1.7 & 2.2 \\
\hline Spain & 0.7 & 0.6 & 0.6 & 0.6 & 3.1 & 2.8 & 2.5 & 2.5 \\
\hline France & 0.7 & 0.2 & 0.2 & 0.4 & 2.8 & 2.2 & 1.6 & 1.4 \\
\hline Croatia & 0.2 & 0.8 & 1.0 & 0.6 & 2.4 & 2.6 & 2.8 & 2.7 \\
\hline Italy & 0.3 & 0.3 & 0.2 & -0.1 & 1.6 & 1.4 & 1.2 & 0.7 \\
\hline Cyprus & 1.0 & 1.1 & 0.8 & 0.8 & 3.5 & 4.1 & 4.0 & 3.7 \\
\hline Latvia & 0.8 & 1.5 & 1.2 & 1.7 & 4.8 & 4.8 & 4.6 & 5.3 \\
\hline Lithuania & 1.3 & 1.0 & 0.9 & -0.3 & 3.8 & 3.7 & 3.8 & 2.9 \\
\hline Luxembourg & 1.4 & 0.9 & 0.0 & - & 2.8 & 3.2 & 3.1 & - \\
\hline Hungary & 1.3 & 1.3 & 1.1 & 1.3 & 5.0 & 4.8 & 4.8 & 5.2 \\
\hline Malta & 0.6 & 0.9 & 2.5 & 3.6 & 5.0 & 4.6 & 6.2 & 7.9 \\
\hline Netherlands & 0.9 & 0.5 & 0.7 & 0.2 & 2.9 & 3.0 & 2.9 & 2.4 \\
\hline Austria & 0.8 & 0.9 & 0.3 & 0.3 & 2.8 & 3.2 & 2.8 & 2.4 \\
\hline Poland & 1.2 & 1.6 & 1.1 & 1.7 & 4.6 & 5.0 & 5.2 & 5.7 \\
\hline Potrugal & 0.8 & 0.4 & 0.6 & 0.3 & 2.5 & 2.2 & 2.4 & 2.1 \\
\hline Romania & 0.4 & 0.3 & 1.5 & 1.9 & 6.6 & 4.3 & 4.3 & 4.1 \\
\hline Slovenia & 2.0 & 0.6 & 0.9 & 1.3 & 6.3 & 5.1 & 4.6 & 5.0 \\
\hline Slovakia & 1.1 & 1.0 & 1.2 & 1.1 & 3.7 & 3.9 & 4.3 & 4.5 \\
\hline Finland & 0.7 & 0.9 & 0.3 & 0.4 & 2.7 & 2.5 & 2.3 & 2.5 \\
\hline Sweden & 0.6 & 0.8 & 0.5 & -0.2 & 2.7 & 3.3 & 2.6 & 1.7 \\
\hline UK & 0.4 & 0.1 & 0.4 & 0.6 & 1.4 & 1.1 & 1.2 & 1.5 \\
\hline
\end{tabular}

Source: Eurostat

Comparing GDP growth rates by quarter, it is clear that, globally, they are positive with minor or major variations by countries. Gross domestic product (GDP) growth is the precondition for sustainable development.(Milosavljević, Pantelejić, \& Međedović, 2019) Cases of negative growth rates are in Germany in the last quarter, as well as in Italy and Lithuania. Other countries achieved positive GDP growth. In most countries quarterly growth is below $1 \%$, but there are cases when it varies considerably. In Malta in the last quarter of 2018 growth rate was 3.6\%. It should be emphasized that in Ireland in the last quarter of 2017 was recorded a significant growth rate of $2.6 \%$ compared to the previous quarter of the same year. 
Considering the time period of one year and comparing the growth rates of the same quarters in consecutive years results and conclusions are similar. Positive growth rates are clearly visible in Denmark in the first quarter of 2018. Rate values vary, with the highest growth rate in Ireland in the first quarter of 2018, when GDP growth was $10.2 \%$ compared to the same quarter of the previous year. Slovakia is an example of the country with not only a positive rate of growth of GDP, but also the rates are higher for every consecutive quarter, and because of that is unique country in the list of countries in the table.

Slovenia is experiencing growth rates that are exceptional but the trend is declining. Positive GDP growth rates and employment rates evident in the EU member states should be achieved through economic policy measures in transition countries as they are necessary in the process of accession to the European Union.(Petrović, 2019) Positive rates of GDP growth and employment in the most EU countries indicate coordinated policies on the most important economic categories, and the harmonization process will certainly improve results.(Sterlacchini, 2009) The importance of GDP and employment growth is important not only for the economic progress of the country but also for raising the level of conscience of the importance of ecology as one of the important factors of overall social well-being. (Gardiner, \& Hajek, 2017)

\section{Research methodology}

In purpose of examining the dependence of the GDP growth rate and employment rate was used the SPSS software package within correlation and regression analysis. The reasons for this type of analysis are explained in the introductory part and refer to the recommendations of numerous authors. The data used was taken from Eurostat and will be presented in the next section of the discussion of the results.

An interpretation of the Pearson correlation coefficient (in the case of a normal distribution) will show the strength of the relationship and the significance level $p$ the statistical significance of the result.

In theoretical considerations, the following models are used:

$X$ - growth rate of gross domestic product $(G D P)$

$Y$ - employment growth rate

The sum of the squares of the variable $X$ is equal to the sum of the squares of the deviation of the value of the variable $X$ from its average value:

$$
S S x x=\sum_{i=1}^{n}\left(X_{i}-\bar{X}\right)^{2}
$$

The average value of the variable $X$ is equal:

$$
\bar{X}=\frac{1}{n} \sum_{i=1}^{n} X_{i}
$$

The sum of squares of variable $Y$ is equal to the sum of squares of the deviation of the value of variable $X$ from its average value:

$$
S S y y=\sum_{i=1}^{n}\left(Y_{i}-\bar{Y}\right)^{2}
$$


The average value of the variable $Y$ is equal:

$$
\bar{Y}=\frac{1}{n} \sum_{i=1}^{n} Y_{i}
$$

The sum of the product of the variables $X$ and $Y$ is equal to the sum of the product of the deviation of the values of the variables $X$ and $Y$ from their averages:

$$
S S x y=\sum\left(X_{i}-\bar{X}\right)\left(Y_{i}-\bar{Y}\right)
$$

The correlation coefficient is equal to the ratio:

$$
r=\frac{S S x y}{\sqrt{S S x x * S S y y}}
$$

After correlation was examined the dependence of the growth of employment rate on the growth rate of gross domestic product(GDP), and the theoretical representation of the model can be presented as:

$$
\begin{aligned}
& Y_{i}=a+b X_{i}+\in_{i} \quad i=1,2, \ldots . ., N \\
& Y_{i}-i \text {-th dependent variable (employment growth rate) } \\
& X_{i}-i \text {-th independent variable (GDP growth rate) } \\
& a, b \text { - constants, regression parameters } \\
& \epsilon_{i} \text { - residuals }
\end{aligned}
$$

The least squares method implies that the parameters of the model are estimated so that the sum of the squares of the residuals, i.e. vertically measured deviations of the sample data from the points on the regression line estimated from the sample:

$$
\sum_{i=1}^{n} \epsilon_{i}^{2}=\sum_{i=1}^{n}\left(Y_{i}-\bar{Y}\right)^{2}=\sum_{i=1}^{n}\left(Y_{i}-\left(\hat{a}+\hat{b} Y_{i}\right)\right)^{2}
$$

be minimal.

For the regression linear equation $Y=a+b X$, the estimates for the parameters $a$ and $b$ are

$$
\begin{aligned}
& \hat{a}=\bar{Y}-\hat{b} \bar{X} \\
& \hat{b}=\frac{\cos (X, Y)}{\operatorname{Sn} x^{2}}
\end{aligned}
$$

It is confirmed that the estimates achieved by this method are the best linear estimates, objective and stable.

The coefficient of determination can be used to check the quality of the model evaluation:

$$
R^{2}=1-\frac{\sum_{i=1}^{n}\left(Y_{i}-\hat{Y}_{i}\right)^{2}}{\sum_{i=1}^{n}\left(Y_{i}-\bar{Y}\right)^{2}}
$$

which will be used and the value of the model will depend on $R^{2}$ and its proximity to value 1 . 


\section{Results and discussion}

Correlation and regression analyzes were used to examine the relationship between growth rates of GDP and employment. The importance of implementation of this analysis will have significant effects on many spheres of social life.(Amores \& Castilo, 2017) GDP and employment trends can also have significant effects on gas emissions.(Barker et al., 2016) The idea of implementation this analysis is also based on the results of the same analysis in the case of Hong Kong.(Chiang, Tao, \& Wong, 2015) Preliminary tests of normality of distribution and homogeneity of variance were done in order to be able to implement correlation analysis. Tests results justified the use of the Pearson correlation coefficient. The value of the Person's correlation coefficient will be presented in the following table.

Table 4: Results of correlation analysis

\begin{tabular}{|c|c|}
\hline \multicolumn{2}{|c|}{ Correlations (Spreadsheet1) Marked correlations are significant at $\mathbf{p}<\mathbf{. 0 5 0 0 0}$ (Casewise deletion of } \\
missing data)
\end{tabular}

Source: Authors' representation based on SPSS

The relationship between employment and GDP is also statistically significant, since $p<0.05$, and accomplished correlation is characterized by the character of moderately positive dependence.

Regression analysis was used to show the justification of the model and served to formulate the regression equation.

Table 5: Results of the regression analysis

\begin{tabular}{|c|c|}
\hline $\begin{array}{c}\text { Dependent } \\
\text { Varable }\end{array}$ & Employment \\
\hline $\begin{array}{c}\text { Multiple } \\
\mathbf{R}\end{array}$ & 0,364 \\
\hline $\begin{array}{c}\text { Multiple } \\
\mathbf{R}^{2}\end{array}$ & 0,533 \\
\hline $\begin{array}{c}\text { Adjusted } \\
\mathbf{R}^{2}\end{array}$ & 0,099 \\
\hline $\begin{array}{c}\text { SS } \\
\text { Model }\end{array}$ & 6,860 \\
$\begin{array}{c}\text { df } \\
\text { Model }\end{array}$ & 1 \\
\hline $\begin{array}{c}\text { SS } \\
\text { Residual }\end{array}$ & 6,860 \\
\hline $\begin{array}{c}\text { Df } \\
\text { Residual }\end{array}$ & 44,652 \\
\hline $\begin{array}{c}\text { MS } \\
\text { Residual }\end{array}$ & 1,717 \\
\hline F & 3,994 \\
\hline $\mathbf{p}$ & 0,046 \\
\hline
\end{tabular}

Source: Authors' representation based on SPSS 
Regression analysis shows that GDP explains $53.3 \%$ of the total variance, which makes this model justifiable and it is possible to formulate a regression equation.

\section{Regression Equation: Employment $=1.76+0.608 * G D P$}

A similar analysis was conducted by Popescu(2016). The analysis was based on establishing the correlation between GDP and unemployment in the period 20032014. The results are statistically significant. A strong negative link was found between GDP and unemployment, $r=-0.829$, which is once again a confirmation of the link between employment/unemployment and GDP.

\section{Conclusion}

Focusing on budget policy is the feature of modern states. This is a result of the weakness of the mechanisms that led to the significant amounts of public debts and budget deficits. The allocation of budgetary resources has the influence on the most important macroeconomic aggregates in order to achieve a significant level of GDP and employment growth. Many authors have studied these categories and examined the dependence of macroeconomic indicators. This paper examines the correlation of GDP and employment as well as the statistical validity of the results. The subject of analysis is data of the movement of these categories in the EU Member States. The result serve as an indicator of the successful implementation of economic policy measures and these measures must also be used by countries in transition in order to join the European Union. The results shows positive trends in both GDP growth and employment rates. Statistical analysis of the data was done in the SPSS software program. A moderate positive correlation between GDP and employment was found, $r=0.365$ and the results are statistically significant $\mathrm{p}<0.05$. The significance of these result which is established correlation, is reflected in the necessity of systematically enacting economic measures whose positive consequences can be multiplied just as negative, which was often the case in the past. Entering the recession phase is inevitable in the economic cycle, but the losses incurred in this phase of the economic cycle must be such that, upon entering the prosperous phase, they can be quickly offset.

\section{References}

Amores, R., \& Castilo, S. (2017). Ecuadorian SMEs: Their impact on employment as a contribution of SME GDP to total GDP. Revista Espacios, 38(53), 38-43.

Barker, T., Alexandri, E., Pollitt, H., Mercure, J., \& Ogawa, Y. (2016). GDP and employment effects of policies to close the 2020 emissions gap. Climate Policy, 16(4), 393-414

Chiang, Y.H., Tao, L., \& Wong, F.K.W. (2015). Causal relationship between construction activities, employment and GDP: The case of Hong Kong, Habitat International. 46(1), 1-12 
Ciuhu,A., \&Vasilie, V.(2018).Measuring theeconomicgrowth usingemploymentquality parameters - an econometric approach. Annals of the University of Oradea: Economic Science, 28(1), 287-296

Dugalić, V. (2017). Growth of Serbia’s GDP. Bankarstvo, 46(1), 6-11

Đuričin, S. (2011). Tranzicija i kretanje zaposlenosti u javnom i privatnom sektoru. Aktivne mere na tržištu rada i pitanja zaposlenosti. Institut ekonomskih nauka, Beograd

Gardiner, R., \& Hajek, P. (2017, April). Impact of GDP, capital and employment on waste generation-The case of France, Germany and UK regions, 8th International Conference on E-Business, Management and Economics, ICEME 2017, 94-97

Ines, K-Š., Cinzia, Z. (2009). Utjecaj izravnih inozemnih ulaganja na rast BDP, na zaposlenost i na izvoz u Hrvatskoj. Ekonomski Pregled, 60 (3-4), 119-151.

Jovanović, M. (2018). Humani kapital i održivost ruralnih područja Evropske Unije. Economics of Sustainable Development, 2(1), 61-72.

Kovačević, M., \& Pavlović, N. (2016). Globalizacija i društvo znanja. Ekonomika, 62(4), 95-104.

Malešević-Perović, L. (2008). Subjektivno ekonomsko zadovoljstvo u tranzicijskim zemljama: istraživanje relativne važnosti makroekonomskih varijabli. Financijska teorija i praksa 32 (4), 523-542

Milosavljević, S., Pantelejić, Đ.,\& Međedović, D. (2019). Primena i mogućnost unapređenja ekonomskih činilaca u realizaciji održivog razvoja. Održivi razvoj, $1(1), 7-14$

Mordecki, G., \& Ramirez, L. (2018). Which comes first: GDP growth or investment? the case of a small open economy. Trimestre Economico, 85(337), 115-136

Myślińska, K. (2006). Common Movement in Dynamics of Employment and GDP in Poland in 1996-2004. Acta Universitatis Lodziensis. Folia Oeconomica, 201, 43-52.

Košutić, A., \& Hadžić, M. (2019). Investments of the EBRD in the infrastructure sector of Serbia. International Review, (1-2), 39-63.

Paul, S. (2001). A Welfare Loss Measure of Unemployment with an Empirical Illustration. The Manchester School, 69 (2), 148-163.

Petrov, V., \& Trivić, N. (2018). Problem definisanja i merenja održivog dohotka. Anali Ekonomskog fakulteta u Subotici, 39, 19-31.

Popescu, A. (2016, May). Research on the relationship between GDP, unemployment and employment in the EU-28. 27th IBIMA Conference, Italy

Simić, N., Kosumi, T., \& Jialiang, Y. (2019). Regulatorni instrumenti održivog razvoja. Održivi razvoj, 1(1), 15-26.

Sterlacchini, A. (2009). Assessing the Knowledge Economy: Gdp, Productivity and Employment Growth in Eu Developed Regions. IUP Journal of Knowledge Management,7 (5/6), 58-63.

Tesić, A., Ilić, V., \& Djelić, A. T. (2015). Labour market in Serbia-an opportunity or limitation of economic growth. Economics of Agriculture, 62(4), 1117-1136. 
Joldić, N., Vasiljević, S., \& Krstić, S. (2018). Globalne ekonomske krize kao posledica kapitalizma. Oditor - časopis za Menadžment, finansije i pravo, 4(1), 52-62.

Winkelmann, L. \& Winkelmann, R. (1997). Why Are the Unemployed So Unhappy? Evidence from Panel Data, Economica, 65, 1-15.

Zrinščak, S. (1997). Zaposlenost, nezaposlenost i neslužbeno gospodarstvo. Revija za socijalnu politiku, 4(3), 91-96.

Petrović, R. (2019). Političke posledice ekonomske krize u Španiji. Oditor - časopis za Menadžment, finansije i pravo, 5(1), 7-18.

Eurostat, available on (https://ec.europa.eu/eurostat/web/lfs/data/database). 